\title{
Management Approaches to Reduce Livestock Losses from Poisonous Plants on Rangeland
}

\author{
WILLIAM C. KRUEGER AND LEE A. SHARP
}

Highlight: Early approaches to management for the purpose of reducing or minimizing animal losses due to plant toxins were those of avoiding the areas with poisonous plants or eradicating these plants where feasible. As knowledge and information accumulated through scientific investigations and, often, through experience gained by livestock producers, other techniques could be followed. With a growing understanding of what plants are poisonous and the nature of the toxins, along with the conditions under which toxins are elaborated in the plant, management strategies have been improved.

Poisonous plants on rangelands in the western United Statcs cause significant economic losses to ranchers. Direct losses due to death of animals have been estimated at 3-5\% of livestock grazing on range and the estimates of losses have been similar for about the last 20 years (Marsh 1924; Agricultural Research Service 1968). Losses due to decreased production of animals poisoned but not killed and costs of specialized management practices to avoid poisonous plants probably exceed the cost of death losses. Research to define specific toxic agents, prevention and cure of animal poisoning by plants, ecological status and function of poisonous plants, palatability, and other factors which must be understood eventually to alleviate the problem has been conducted for the last 70 years in the western United States. From this research base and from observations of ranchers and scientists, we can usually

\footnotetext{
The authors arc associate professor, Rangeland Resources Program, Oregon State University, Corvallis, and professor of Range Resources, College of Forestry, Wildlife and Range Sciences, University of Idaho, Moscow, respectively.

The report was submitted as Technical Paper No. 4784. Oregon Agricultural Experiment Station, Corvallis.

Manuscript received March 30, 1978.
}

minimize livestock losses from plant poisoning by carefully defining management programs. While the principles and practices reported in this paper were derived largely from research and experiences in the western United States, they should be applicable, perhaps with modification, to other parts of the world.

Sampson (1952) indicated there were more than 500 species of poisonous plants in the United States, while Stoddart et al. (1975) suggested that thousands of plants would be poisonous if eaten in large quantity. However, on most rangclands poisonous plants are not eaten in sufficient quantity to cause easily identifiable production losses or death of livestock. Poisonous plants must generally be consumed in relatively large quantities to be toxic. It is this fact which allows development of vegetation and livestock management programs to make productive use of rangelands that support poisonous plant species. Some poisonous plants such as water hemlock (Cicuta spp.) and timber milkvetch (Astragalus spp.) are toxic in relatively small amounts (Kingsbury 1964). Management of areas with these highly toxic plants will generally be more specialized than in most other cases.

\section{Vegetation Manipulation to Minimize Livestock Losses}

When an entire pasture supports a sufficient amount of poisonous plants to present risk to grazing of livestock, it may be economical to consider overall improvement of the pasture. Poisonous plants are usually minor constituents of good condition rangeland and increase in abundance if grazing is excessive (Stoddart et al. 1949). If the range has not retrogressed beyond a stage where a positive response to grazing management is possible, good grazing management 
should return the community to a state where poisonous plants do not present a hazard to livestock. However, it is frequently the case, especially in more arid environments, that a plant community will not respond to grazing management in a reasonable time frame. For example, complete protection from grazing over 20 to 25 years has not resulted in significant changes in certain sagebrush (Artemisia tridentata) dominated plant communities (Tisdale, et al. 1969). Under these circumstances a type conversion may be necessary to solve the problem of poisonous plants and return the range to its original productivity. Once the stand of improved vegetation is established, the pasture can be grazed profitably, but residual poisonous plants may still need to be considered in the grazing program. Even under good range management, poisonous plants such as bitterweed (Hymenoxys odorata) may become abundant in response to drought or other unusual weather conditions (Bunting and Wright 1974). Since eradication of poisonous plants over large areas is seldom possible, vegetation manipulation should be integrated with livestock management programs that minimize the intake of these plants.

Direct control of problem plants is sometimes successful. Most poisonous plants are forbs or shrubs and can be killed by one of the phenoxy herbicides without damage to grasses in the plant community. Response of vegetation to herbicides may vary with the site (Cronin, et al. 1977). Often a second treatment is needed to successfully minimize the density of these plants. Spraying with herbicides will seldom eradicate poisonous plants completely, but coupled with proper grazing management it will often reduce them to a "safe" level. Certain poisonous plants have been successfully controlled by biological agents. The most notable among these are St. Johnswort (Hypericum perforatum), which has been successfully controlled by introduction of two beetles (Chrysolina gemellata) and (C. hyperici), and tansy ragwort (Senecio jacohea) which has been locally controlled by larvae of the cinnabar moth (Tyria jacobeae) on the west coast of North America (Vallentine 1971). Grazing of livestock that are resistant to toxic effects of poisonous plants has also been useful in minimizing grazing hazard for less resistant animal species. For example, sheep have been used to control tansy ragwort and thus improve the range for cattle.

Frequently, poisonous plants are localized within a pasture and control or eradication becomes necessary to allow its full use. Localized stands of poisonous plants may result from either natural site differences or developments (usually watering points), and sometimes a relatively small stand of poisonous plants can have major impact on the livestock herd. Nielsen and Cronin (1977) reported results of spot treatment of tall larkspur (Delphinium barbeyi) in Utah. A pasture of 8,000 acres had 344 acres of larkspur which caused an average loss of 33 cows and 10 calves each year. Spot treatment of larkspur in this pasture proved to be an excellent investment with an internal rate of return which varied from $63 \%$ to $72 \%$ based on value of livestock saved. While costs of controlling or eradicating poisonous plants may be high on a per-acre basis, the impact on the total pasture should frequently make spot treatment a highly profitable practice. When it is not possible or desirable to control spot infestations, they may be isolated from the livestock herd by fencing. This practice has been especially beneficial around water developments.
Where it is profitable to manage the plant community to minimize the hazard to livestock from poisonous plants there are frequently other benefits of value to the rancher or land manager. Control of poisonous plants often will allow greater flexibility in management by increasing the length of time a pasture can be grazed in a season. In turn, this can allow development of grazing programs to make better use of the total range and increase productivity of pastures whose use was previously dependent upon special grazing practices in the pasture with poisonous plant hazards. When poisonous plants are no longer a problem, a pasture can frequently be stocked at a heavier rate, which will also defray costs of improvement.

Manipulation of vegetation may also introduce certain hazards that need to be considered. Spraying of poisonous plants may increase both their toxicity and palatability (Agricultural Research Service 1968) and deferring grazing until the plants have dried and other vegetation has grown to provide a substantial forage source is recommended. Usually, dead vegetation loses its toxicity, but certain plants like locoweed (Astragalus spp.) remain toxic when dried (James et al. 1968). Another problem that may result from intensified management is nitrate poisoning following application of high levels of nitrogen fertilizer to rangeland. This tends to be specific to certain plant species. Houston et al. (1973) reported accumulation of nitrate nitrogen in excess of safe levels in annual forbs of mixed prairie vegetation after high rates of nitrogen fertilizer (224-672 $\mathrm{kg} / \mathrm{ha}$ ). Such nitrate accumulation in forbs may last for 3 years. When nitrate-accumulating forbs are present, it may be necessary to control them to allow safe grazing of the grasses.

\section{Livestock Management to Minimize Poisoning}

It is only recently that effective and economical treatment of rangeland has been developed to reduce the dangers of livestock grazing plant communities supported poisonous plants. For the most part, ranchers have learned to live with poisonous plants and have developed management systems to minimize losses of livestock. Trial and error, in part, based on programs of scientific investigations, have resulted in satisfactory grazing prescriptions for most potentially dangerous situations.

In order to deal effectively with a problem, a certain level of basic knowledge is necessary. The manager must be able to recognize the poisonous plants on the range, know how they affect livestock, and the conditions under which they are poisonous. Once it is determined that a problem from a poisonous plant exists, either through identification of the plant or actual livestock losses, a management program specific to the plant in question can be developed.

Most people with experience in the field agree that good management will usually prevent poisoning of livestock. Poisonous plants generally have three common characteristics: (1) they are usually unpalatable; (2) the toxin within the plant frequently decreases or dilutes as the plant matures; (3) herbaceous poisonous plants usually begin growth early in the spring and become proportionally less abundant as other vegetation begins its annual growth cycle. Understanding these features in detail for all poisonous plants on a particular range will allow the grazier to make substantial use of desirable forages and minimize losses due to toxins in the vegetation. 
Since poisonous plants are usually unpalatable, they do not usually present a problem unless other forage is limited in availability or reduced in palatability. Consequently, on seasonal rangelands of the Northwest, most livestock losses to poisonous plants occur in early spring or fall. Deferment until range readiness for the major forage species will frequently prevent livestock poisoning on spring range. Early removal of livestock in fall may be necessary on some mountain ranges. These simple changes on well-managed rangelands may nearly eliminate losses due to poisonous plants. Teratogenic problems from plants like western false hellebore (Veratrum californicum) can be avoided with proper timing of grazing (James and Johnson 1976).

Preference patterns of livestock for different forages will change if they are hungry. This can occur when the range is heavily grazed, livestock are trailed or shipped, water intake is reduced, or when animals have been held off feed such as during shearing or branding. A hungry animal should not be allowed access to poisonous plants since they are prone to eat less selectively until they are satiated. Trailing or driving livestock slowly when moving them, avoiding heavy grazing, and providing sufficient water in areas with poisonous plants should minimize their consumption of poisonous plants. When animals must be fasted, such as during shipping or shearing, they should be turned onto range free of poisonous plants or provided a sufficient amount of supplemental feed to relieve their hunger. If areas are infested with large amounts of poisonous plants, livestock should not be held there for long periods since the limited supply of forage can be rapidly depleted. If animals must be held on areas with heavy infestations of poisonous plants, an alternative feed, such as hay, should be supplemented.

Some plants are highly toxic, such as those in the Cicuta genus, and management programs to deal with them are usually designed to avoid contact. This may be accomplished with herding of sheep or fencing for cattle. If the infestation of highly toxic plants is not extensive, the stand may be eradicated to remove the hazard.

Since most poisonous plants must be consumed in relatively large quantities to be damaging, some specialized programs have been developed to maintain individual animal intake below toxic levels. Everist (1974) discussed management of sheep to prevent ingestion of toxic amounts of darling pea (Swainsona spp.). In this instance heavy, short duration grazing of a few days was used to remove the relatively palatable pea before any animals could be permanently affected. Certain sheep are more prone to eat the pea than others. Thus, light grazing over a long period would allow the "pea eaters" to consume enough of this plant to cause permanent brain injury. Stoddart et al. (1949) discussed management of sheep on range with high amounts of sneezeweed (Helenium hoopesii). In this case, sheep herders removed the sheep from sneezeweed areas for a few days about every 3 weeks. This apparently prevented accumulation of dangerous quantities of dugaldin, the toxic principle. Halogeton (Halogeton glomeratus) has been a major problem for sheep growers and has killed hundreds of sheep at a time in the salt desert shrub ranges. However, James and Cronin (1974) indicated sheep could adapt to ingestion of relatively high levels of oxalate from halogeton if gradually introduced to it. Adapted sheep can detoxify $75 \%$ more oxalate than sheep not adapted. When sheep are removed from high oxalate-containing feed, they lose the adaptation within 2-3 days. Big sagebrush (Artemisia tridentata) has been shown to be toxic if force fed to sheep at a rate of $3 / 4$ pound per day (fresh weight) for 1 to 3 days. However, sheep were not affected when gradually introduced to the plant with $1 / 4$ pound per day of fresh sagebrush (Johnson et al. 1976).

Frequently, lack of salt or other minerals is associated with livestock grazing poisonous plants (James and Johnson 1976). Most livestock management programs involve providing salt free choice. If other minerals are known to be deficient, usually phosphorus, they should be provided. Livestock deficient in phosphorus will sometimes develop a depraved appetite and eat abnormally. This can be prevented by proper mineral supplementation. When salt and supplement stations are established, areas within or adjacent to heavy infestations of poisonous plants should be avoided since the supplement station will tend to concentrate livestock and increase the risk of poisoning.

All animals do not exhibit the same forage preferences. In areas of concern, new animals introduced into the herd should be watched carefully for a few days. If they are to be poisoned, it will probably occur soon after stocking (Everist 1974). Livestock in different reproductive stages may respond differently to poisonous plants; for example, dry cows are less prone to be affected by timber milkvetch (Astragalus miser) than lactating cows (Williams 1970). It is possible this is due to behavioral differences or variation in total daily intake rather than a basic physiological difference. By far the greatest differences in animal responses to poisonous plants are those among animal species. Sheep and black-tailed deer (Odocoileus hemionus columbianus) are resistant to tansy ragwort, while cattle and horses are susceptible (Dean and Winward 1974). Sheep are relatively resistant to larkspur (Delphinium spp.) while cattle are highly susceptible (Kingsbury 1964). Sheep and cattle are more resistant to locoweed than horses (James et al. 1968). In addition, cattle are seldom lost to halogeton or sneezeweed while these plants are problems for sheep (James and Johnson 1976). By selecting species of livestock to graze specific areas, poisonous plant problems can be minimized. Sometimes one livestock species can "condition" the range to permit safe grazing by the other.

Toxicity of some poisonous plants varies with the site on which they grow. This has been clearly demonstrated for Columbia milkvetch (Astragalus miser var. serotinus) (Majak and McLean 1975 and Majak et al. 1977) in Canada. Milkvetch in shaded, moist timbered sites was lower in miserotoxin than that on open, dry grasslands. Management programs that control seasonal use of these sites could be developed to account for this kind of variation and improve livestock production from these northern ranges.

A few poisonous plants like tall larkspurs (Delphinium spp.) are relatively palatable to livstock, and others like locoweeds (Astragalus spp. and Oxytropis spp.) are addictive. It is difficult to prevent losses when these types of plants are present. If any livestock show symptoms of poisoning under these circumstances, all animals should be removed from the range immediately.

Management programs designed to cope with poisonous plants can be expected to work well year after year. However, unusual weather patterns may cause changes in vegetation that present new problems and one should always be 
alert to special management needs each year. Cyanideproducing plants will produce excessive amounts of hydrocyanic acid when under stress such as drought or frost. Production and composition of range plant communities respond to weather. In a drought year a range may have proportionally more poisonous plants and consequently a risk where none had existed before. Unusual weather patterns may change phenological development of portions of a plant community, and poisonous plants may become prominent at unusual times. The winter of 1976-77 was exceptionally dry in eastern Oregon. Observation and limited sampling indicated there was little usable soil moisture until rains began in May. Cattle losses to low larkspur (Delphinium spp.) do not normally occur after mid-May in the area, but because of delayed growth of larkspur in 1977, losses began to occur in late May.

Most studies of poisonous plants have dealt with direct effects of ingesting toxic amounts of them. Losses are described in terms of death, abortions, photosensitization, and other obvious signs of distress. On the other hand, sub-lethal effects of consumption of toxic plants have not been well documented. Some evidence suggests that animals grazing rangelands with an abundance of poisonous plants are less efficient or produce smaller offspring (Doran and Cassady 1944). Ewes fed locoweed produce lambs that appear normal but have a shortened life span (Balls et al. 1973) and reproductive desires and spermatogenesis in the male and estrus in the female are suppressed with loco poisoning (James and Van Kampen 1971). Indirect losses from consumption of sub-lethal amounts of plants may be important. If the truth of this is confirmed, then management to adapt animals to certain toxins or prcvent ingestion of toxic amounts may not be beneficial in the long run.

Treatment of poisoned animals is seldom practical on rangelands (Everist 1974). Effects of many poisonous plants have no known treatment or the intoxication may be too far advanced to treat. When poisoned animals are discovered, they should be removed from the pasture if it does not involve great disturbance and kept quiet and away from water for several hours. Everist (1974) has suggested treatments for cyanide (prussic acid) poisoning, nitrate poisoning, and oxalate poisoning. These are effective and should be tried when the nature of the poisoning is understood.

All problems with poisonous plants cannot be predicted or effectively prevented or alleviated by management. In some cases, at least with our present state of knowledge, the manager must accept losses in production or not use the range area where poisonous plants or poisoning conditions occur. However, good range management, understanding of poisonous plants on the range, and common sense animal management can keep losses to a minimum.

\section{Literature Cited}

Agricultural Research Service. 1968. 22 plants poisonous to livestock in the western states. U.S. Dep. Agr. Agr. Inform. Bull. No. 327.

Balls, L. D., and L. F. James. 1973. Effect of locoweed (Astragalus spp). on reproductive performance of ewes. J. Amer. Vet. Med. Ass. 162: 291-292.

Bunting, S. C., and H. A. Wright. 1974. Controlling bitterweed with fall and winter applications of 2,4-D amine. J. Range Manage. 27:381-382.

Cronin. E. H., J. E. Bowns, and A. E. Johnson. 1977. Herbicides, nitrogen, and control of tall larkspur under aspen trees. J. Range Manage. $30: 420-422$.

Dean, R. E., and A. H. Winward. 1974. An investigation into the possibility of tansy ragwort poisoning of blacktailed deer. J. of Wildl. Dis. 10:166-169.

Doran, C. W., and J. T. Cassady. 1944. Management of sheep on range infested with orange sneezeweed. U.S. Dep. Agr. Circ. No. 691

Everist, S. L. 1974. Poisonous Plants of Australia. Angus and Robertson. Sydney, Australia.

Houston, W. R., L. D. Sabatka, and D. N. Hyder. 1973. Nitratenitrogen accumulation in range plants after massive $\mathrm{N}$ fertilization on shortgrass plains. J. Range Manage. 26:54-57.

James, L. F., K. L. Bennett, K. G. Parker, R. F. Keeler, W. Binns, and B. Lindsay. 1968. Loco plant poisoning in sheep. J. Range Manage. 21:360-365.

James, L. F., and E. H. Cronin. 1974. Management practices to minimize death losses of sheep grazing halogeton-infested range. J. Range Manage. 27:424-426.

James, L. F., and A. E. Johnson. 1976. Some major plant toxicities of the western United States. J. Range Manage. 29:356-363.

James, L.F., and R.K. Van Kampen. 1971. Effects of locoweed intoxication on the genital tract of the ram. Amer. J. Vet. Res. 32:1253-1256.

Johnson, A. E., L. F. James, and J. Spillett. 1976. The abortifacient and toxic effects of big sagebrush (Artemisia tridentata) and juniper (Juniperus osteosperma) on domestic sheep. J. Range Manage. 29:278-280.

Kingsbury, J. M. 1964. Poisonous Plants of the United States and Canada. Prentice-Hall, Inc. Englewood Cliffs, New Jersey.

Majak, W., and A. McLean. 1975. Variability of miserotoxin concentration in timber milkvetch. J. Range Manage. 28:362-364.

Majak, W., P. D. Parkinson, R. J. Wiliams, N. E. Looney, and A. L. Van Ryswyk. 1977. The effect of light and moisture on Columbia milkvetch toxicity in lodgepole pine forests. J. Range Manage. 30:423-427.

Marsh, C. D. 1924. Stock poisoning plants of the range. U.S. Dep. Agr. Dep. Bull. 1245.

Nielsen, D. B., and E. H. Cronin. 1977. Economics of tall larkspur control. J. Range Manage. 30:434-438.

Sampson, A. W. 1952. Range Management - Principles and Practices. John Wiley and Sons, New York.

Stoddart, L. A., A. H. Holmgren, and C. W. Cook. 1949. Important poisonous plants of Utah. Utah Agr. Exp. Sta. Special Rep. 2.

Stoddart, L. A., A. D. Smith, and T. W. Box. 1975. Range Management. McGraw-Hill Book Co. New York.

Tisdale, E. W., M. Hironaka, M. A. Fosberg. 1969. The sagebrush region in Idaho - a problem in range resource management. Idaho Agr. Exp. Sta. Bull. 512 .

Vallentine, J. F. 1971. Range Development and Improvements. Brigham Young University Press. Provo, Utah.

Williams, M. C. 1970. Detoxification of timber milkvetch by $2,4,5-T$ and silvex. J. Range Management. 23:400-402. 